\title{
Rancang Bangun Sistem Identifikasi Arus Lalu Lintas pada Simpang Tiga Menggunakan Database NoSQL
}

http://dx.doi.org/10.28932/jutisi.v6i2.2567

\author{
Muhammad Alkaff ${ }^{\bowtie \# 1}$, Iphan Fitrian Radam ${ }^{* 2}$, Sugiantoro \#3 \\ Teknologi Informasi, Universitas Lambung Mangkurat \\ Jl. Brigadir Jenderal H. Hasan Basry, Banjarmasin \\ ${ }^{1 m}$.alkaffeulm.ac.id \\ ${ }^{3}$ sugiantoro.idegmail.com \\ ${ }^{\#}$ Teknik Sipil, Universitas Lambung Mangkurat \\ Jl. Brigadir Jenderal H. Hasan Basry, Banjarmasin \\ 2ifradameulm.ac.id
}

\begin{abstract}
T-junction is one of the types of intersections that often results in congestion, and long queues. Therefore, it is necessary to identify the traffic flow to determine vehicles per hour, Passenger Car Unit (PCU) per hour, traffic fluctuations, vehicle composition, trip composition and traffic flow at peak hours at T-junction. The process of identifying traffic flow is complex and involves many variables. The process is currently still using Microsoft Excel which requires a lot of time and energy and allows for human error. Therefore, the purpose of this research is to design and build a traffic flow identification system at T-junction using NoSQL database. NoSQL is useful for complex data because NoSQL eliminates repetitive data. The results of this research are the traffic flow identification system at T-junction using NoSQL database which consists of vehicles per hour, PCU per hour, traffic fluctuations, vehicle composition, trip composition, and traffic flow during peak hours.
\end{abstract}

Keywords-NoSQL Database; Peak Hours; T-Junction; Traffic Flow

\section{Pendahuluan}

Simpang tiga merupakan salah satu jenis simpang jalan berdasarkan bentuknya yang mempunyai tiga lengan [1]. Jenis simpang ini sering terjadi kemacetan dan antrian yang panjang akibat volume lalu lintasnya yang tinggi terutama pada jam puncak [2]-[4]. Evaluasi kinerja suatu simpang tiga digunakan untuk mengoptimalkan fungsi dari simpang tiga. Evaluasi kinerja simpang tak bersinyal melalui tiga proses yaitu, pengumpulan data, pengolahan data dan analisis data [5]. Identifikasi arus lalu lintas pada simpang tiga berfokus pada proses pengolahan data. Identifikasi arus lalu lintas pada simpang tiga merupakan proses pengolahan data pada simpang tiga guna menghasilkan data kendaraan per-jam, satuan mobil penumpang (SMP) per-jam, fluktuasi lalu lintas, komposisi jumlah kendaraan, komposisi pergerakan kendaraan dan data arus lalu lintas pada jam puncak.

Proses identifikasi arus lalu lintas pada simpang tiga saat ini masih menggunakan bantuan software pengolah angka, Microsoft Excel. Terdapat kekurangan dalam penggunaan Microsoft Excel untuk pengolahan data pada simpang tiga yaitu masih terdapat proses yang dilakukan secara manual yaitu proses sort dan filter. Proses sort dan filter merupakan proses menyortir dan menyaring data berdasarkan total nilai tertinggi dari data SMP per-jam. Proses sort dan filter ini ditujukan untuk menentukan arus lalu lintas pada jam puncak suatu simpang tiga. Proses ini membutuhkan tenaga dan waktu yang banyak karena harus melakukan sort dan filter secara manual pada data yang sangat kompleks. Selain itu, membutuhkan ketelitian dalam melakukan sort dan filter pada data survei yang kompleks sehingga berpotensi menimbulkan kesalahan human error dalam penentuan arus lalu lintas pada jam puncak di suatu simpang tiga. Microsoft Excel tidak dapat menyimpan data historis sebelumnya. Karena hanya dapat melakukan pengolahan data dalam satu hari saja, tidak menyimpan data historis sebelumnya, maka tidak dapat melihat pola data per-harinya atau per-minggu maupun per-tahun.

Proses pengolahan data pada simpang tiga merupakan proses yang kompleks melibatkan data survei lalu lintas yang terdiri atas beberapa variabel seperti geometrik simpang, lalu lintas, data survei, kendaraan per-jam dan satuan mobil penumpang. Oleh karena itu perlu ditunjang dengan database yang sesuai. NoSQL lebih baik untuk data yang kompleks atau dalam jumlah besar daripada $M y S Q L$ [6]. Permasalahan pengolahan data yang kompleks pada 
simpang tiga misalnya pada variabel lalu lintas, jika menggunakan RDBMS akan memerlukan banyak tabel agar tidak terdapat redundansi data. RDBMS membutuhkan 4 buah tabel hanya untuk variabel data lalu lintas. Penyelesaian dengan NoSQL yaitu pada NoSQL dimana halhal yang menyebabkan redundansi akan dihilangkan. Basis data MySQL atau RDBMS lebih sesuai untuk data terstruktur sedangkan basis data $N o S Q L$ lebih sesuai untuk data tidak terstruktur dan data semi terstruktur [7]. Berbeda dengan RDBMS yang membutuhkan 4 tabel hanya untuk variabel data lalu lintas, dengan menggunakan NoSQL hanya membutuhkan 1 koleksi saja untuk mencakup variabel tersebut. NoSQL dapat menyederhanakan proses dalam penyimpanan data yang kompleks, sehingga trafik server seimbang. Dalam segi performansi NoSQL lebih cepat dibandingkan dengan MySQL [8]. Database NoSQL lebih baik dibandingkan $M y S Q L$ dalam proses transaksi CRUD [9]. Selain itu, NoSQL mendukung untuk dokumen JSON yang membuat integrasi data dalam beberapa jenis aplikasi lebih mudah dan lebih cepat [10].

Penelitian ini bertujuan untuk merancang dan membangun sistem identifikasi arus lalu lintas pada simpang tiga menggunakan database NoSQL. Melalui penelitian ini diharapkan dapat mempermudah dalam melakukan identifikasi arus lalu lintas pada simpang tiga, menghemat waktu dan tenaga dalam mengidentifikasi arus lalu lintas pada simpang tiga, menghilangkan kesalahan human error dalam penentuan arus lalu lintas pada jam puncak pada simpang tiga dan membantu dalam menyimpan data identifikasi arus lalu lintas pada simpang tiga

\section{Metodologi Penelitian}

\section{A. Deskripsi Umum Penelitian}

Penelitian ini dibangun suatu sistem yang dapat mengidentifikasi arus lalu lintas pada simpang tiga menggunakan database NoSQL. Data survei arus lalu lintas digunakan sebagai data masukan, sedangkan hasil identifikasi arus lalu lintas pada simpang tiga adalah data keluaran. Sistem yang dibangun berbasis website dengan menggunakan bahasa pemrograman PHP dan web framework bernama Laravel. Database NoSQL yang digunakan adalah MongoDB. Model proses rancang bangun yang digunakan adalah metode waterfall. Adapun metode waterfall dapat dilihat pada gambar 1 .

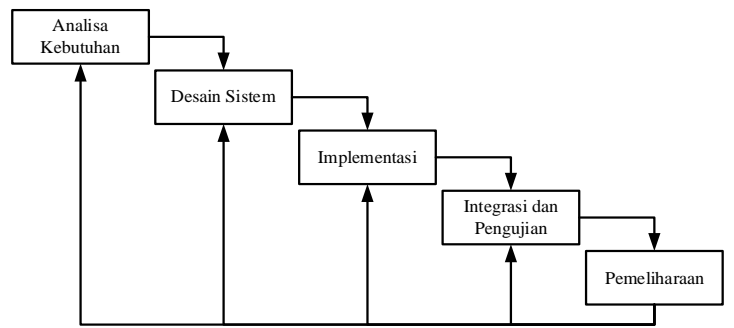

Gambar 1. Metode waterfall rancang bangun

\section{B. Alur Penelitian}

Penelitian rancang bangun sistem identifikasi arus lalu lintas pada simpang tiga menggunakan database NoSQL terdapat alur penelitian yang digunakan untuk mengetahui tahapan-tahapan yang terdapat pada penelitian ini. Adapun alur penelitian dapat dilihat pada gambar 2 .

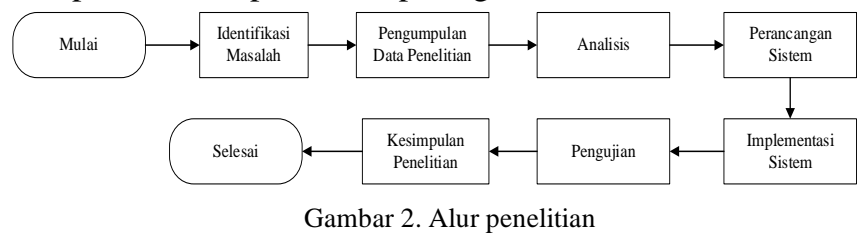

\section{Variabel Penelitian}

Proses pengolahan data pada simpang tiga merupakan proses yang kompleks melibatkan data survei lalu lintas yang terdiri atas beberapa variabel seperti geometrik simpang, lalu lintas, data survei, kendaraan per-jam dan satuan mobil penumpang. Variabel geometrik simpang merupakan inisialisasi simpang tiga seperti tanggal survei, nama jalan di arah utara, nama jalan di arah timur, nama jalan di arah selatan dan nilai ekivalensi. Adapun variabel geometrik pada sheet Microsoft Excel dapat dilihat pada gambar 3 .

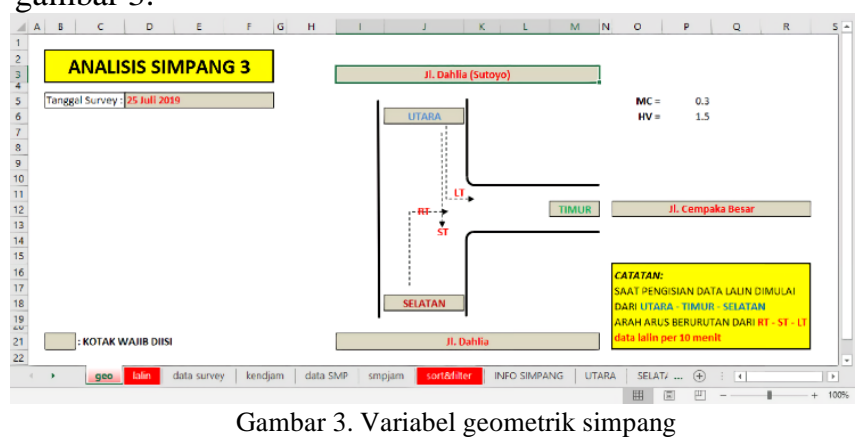

Variabel lalu lintas berisi data lalu lintas dari setiap lengan simpang, dimana setiap lengan simpang mempunyai dua arah jalan yang berarti dalam simpang tiga mempunyai 6 buah data lalu lintas. Setiap data tersebut berisi data kendaraan yang dibagi menjadi 13 jenis kendaraan yang berbeda. Data tersebut diambil dalam 24 jam yang dimulai dari pukul 00.00 hingga pukul 23.50 dengan interval 10 menit. Variabel data survei merupakan data yang berisi pengelompokan dari variabel lalu lintas yang dikelompokkan menjadi empat jenis kendaraan berdasarkan MKJI. Variabel kendaraan per-jam berisi penjumlahan dari variabel data survei dimana setiap jenis kendaraan dijumlahkan setiap satu jam. Variabel satuan mobil penumpang berisi variabel data survei yang dikalikan dengan nilai ekivalensi dari masing-masing jenis kendaraan.

\section{Teknik Pengumpulan Data}

Data yang digunakan dalam penelitian ini merupakan data yang telah tersedia. Teknik pengumpulan data untuk mendapatkan informasi mengenai penelitian rancang 
bangun sistem identifikasi arus lalu lintas pada simpang tiga menggunakan database NoSQL adalah sebagai berikut:

1. Teknik Wawancara, teknik wawancara digunakan untuk teknik pengumpulan data apabila peneliti ingin melakukan studi pendahuluan untuk menentukan permasalahan yang harus diteliti [11]. Teknik ini dilakukan untuk memperoleh informasi secara langsung dari ahli bidang transportasi, serta penjelasan mengenai alur untuk mendapatkan hasil identifikasi arus lalu lintas pada simpang tiga.

2. Teknik Studi Kepustakaan, teknik studi kepustakaan merupakan teknik pengumpulan data dengan mengadakan studi penelaah terhadap buku-buku, literatur-literatur, catatan-catatan, dan laporanlaporan yang ada hubungannya dengan masalah yang dipecahkan [12].

\section{E. Analisis Sistem}

Analisis sistem pada penelitian ini digambarkan menggunakan flowchart. Flowchart atau diagram alir merupakan gambaran secara grafik dari langkah-langkah dan urutan prosedur suatu program [13]. Adapun diagram alir analisis sistem identifikasi arus lalu lintas pada simpang tiga menggunakan database NoSQL dapat dilihat pada gambar 4.

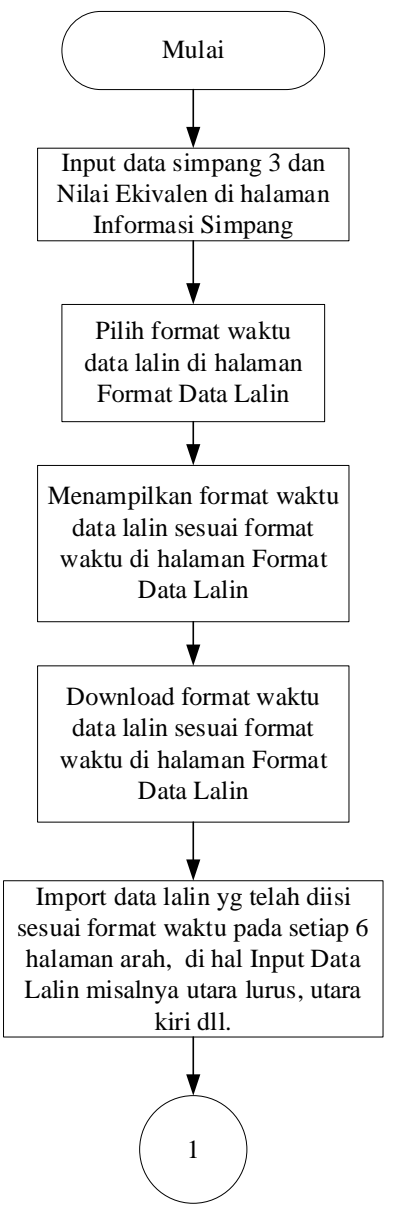

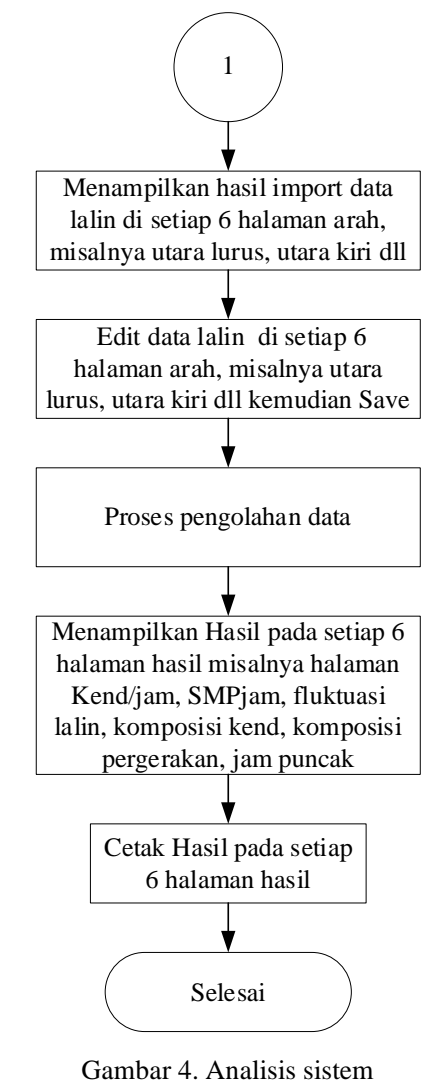

III. HASIL DAN PEMBAHASAN

\section{A. Desain Database NoSQL}

Desain database NoSQL yang digunakan pada sistem identifikasi arus lalu lintas pada simpang tiga adalah database NoSQL MongoDB. Penyimpanan data di database NoSQL dapat digunakan untuk pengembangan sistem selanjutnya seperti pemanfaatan untuk machine learning. Desain database sistem identifikasi arus lalu lintas pada simpang tiga menggunakan MongoDB dapat dilihat pada gambar 5.

\section{trafficapps.DataLaluLintas}

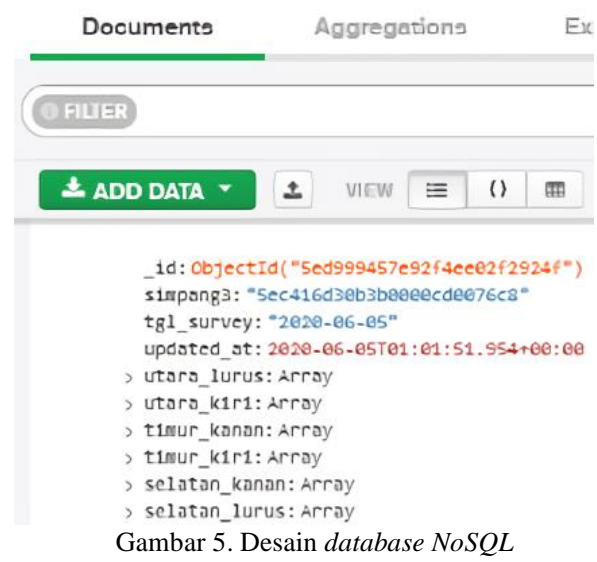




\section{B. Desain Use Case Diagram}

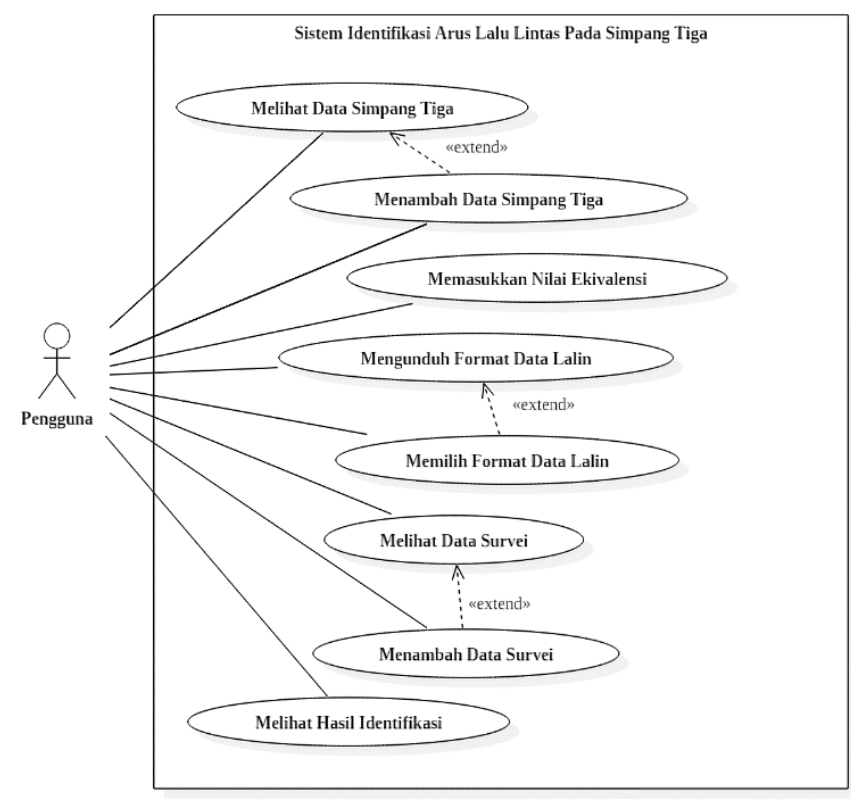

Gambar 6. Use case diagram sistem

Use case diagram pada gambar 6 menunjukkan kelakuan (behavior) sistem yang dapat digunakan oleh pengguna pada sistem identifikasi arus lalu lintas pada simpang tiga. Use case diagram merupakan pemodelan untuk kelakuan (behavior) sistem yang akan dibuat [14]. Pengguna merupakan aktor dalam use case diagram sistem identifikasi arus lalu lintas pada simpang tiga. Karakteristik pengguna yaitu lembaga atau perorangan yang berhubungan dengan proses identifikasi arus lalu lintas pada simpang tiga seperti Dinas Perhubungan, dosen atau mahasiswa teknik sipil. Terdapat 8 aksi yang dapat dilakukan oleh pengguna. Pengguna dapat melihat data simpang tiga, menambah data simpang tiga, memasukkan nilai ekuivalensi, mengunduh format data lalin, memilih format data lalin, melihat data survei, menambah data survei dan melihat hasil identifikasi yaitu data kendaraan per-jam, satuan mobil penumpang perjam, fluktuasi lalu lintas, komposisi jumlah kendaraan, komposisi pergerakan kendaraan dan data arus lalu lintas pada jam puncak. Adapun tabel deskripsi dari use case diagram sistem identifikasi arus lalu lintas pada simpang tiga dapat dilihat pada tabel I.
TABEL I

DESKRIPSI USE CASE DiAgRAM

\begin{tabular}{|c|c|c|c|}
\hline Kode & $\begin{array}{c}\text { Nama Use } \\
\text { Case }\end{array}$ & Aktor & $\begin{array}{c}\text { Deskripsi } \\
\text { Singkat } \\
\end{array}$ \\
\hline UC01 & $\begin{array}{l}\text { Melihat Data } \\
\text { Simpang Tiga }\end{array}$ & Pengguna & $\begin{array}{l}\text { Pengguna dapat } \\
\text { melihat data } \\
\text { simpang tiga }\end{array}$ \\
\hline $\mathrm{UC0} 2$ & $\begin{array}{l}\text { Menambah } \\
\text { Data Simpang } \\
\text { Tiga }\end{array}$ & Pengguna & $\begin{array}{l}\text { Pengguna dapat } \\
\text { menambah data } \\
\text { simpang tiga }\end{array}$ \\
\hline UC03 & $\begin{array}{l}\text { Memasukkan } \\
\text { Nilai } \\
\text { Ekivalensi }\end{array}$ & Pengguna & $\begin{array}{l}\text { Pengguna dapat } \\
\text { memasukkan nilai } \\
\text { ekivalensi }\end{array}$ \\
\hline UC04 & $\begin{array}{l}\text { Mengunduh } \\
\text { Format Data } \\
\text { Lalin }\end{array}$ & Pengguna & $\begin{array}{l}\text { Pengguna dapat } \\
\text { mengunduh } \\
\text { format data lalin }\end{array}$ \\
\hline UC05 & $\begin{array}{l}\text { Memilih } \\
\text { Format Data } \\
\text { Lalin }\end{array}$ & Pengguna & $\begin{array}{l}\text { Pengguna dapat } \\
\text { memilih format } \\
\text { data lalin }\end{array}$ \\
\hline UC06 & $\begin{array}{l}\text { Melihat Data } \\
\text { Survei }\end{array}$ & Pengguna & $\begin{array}{l}\text { Pengguna dapat } \\
\text { melihat data } \\
\text { survei }\end{array}$ \\
\hline UC07 & $\begin{array}{l}\text { Menambah } \\
\text { Data Survei }\end{array}$ & Pengguna & $\begin{array}{l}\text { Pengguna dapat } \\
\text { menambah data } \\
\text { survei }\end{array}$ \\
\hline UC08 & $\begin{array}{l}\text { Melihat Hasil } \\
\text { Identifikasi }\end{array}$ & Pengguna & $\begin{array}{l}\text { Pengguna dapat } \\
\text { melihat hasil } \\
\text { identifikasi. }\end{array}$ \\
\hline
\end{tabular}

\section{Desain Interface Sistem}

Perancangan antarmuka atau desain interface merupakan rancangan suatu sistem yang akan dibuat. Berikut ini merupakan rancangan antarmuka atau desain interface sistem identifikasi arus lalu lintas pada simpang tiga dapat dilihat pada gambar 7-11.

\section{1) Halaman Dashboard:}

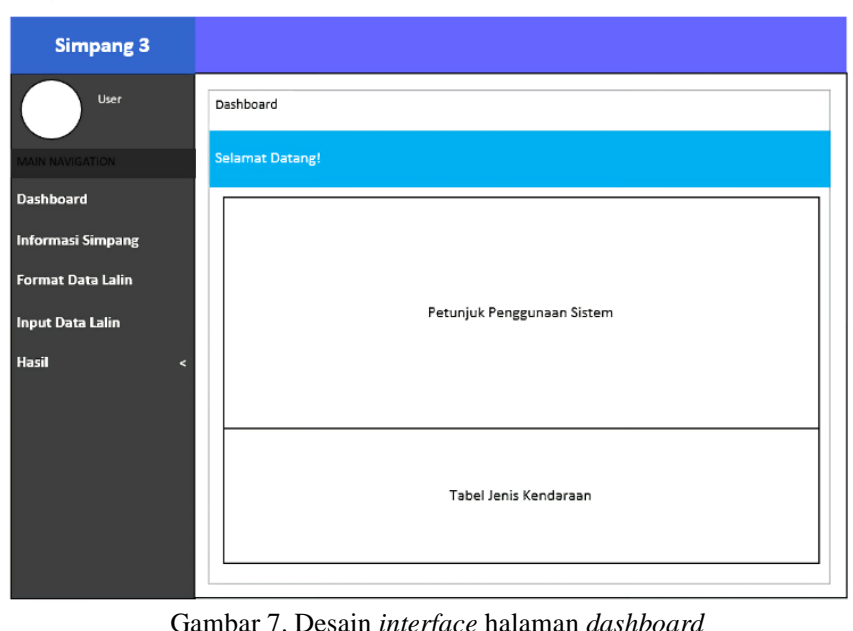




\section{2) Halaman Informasi Simpang:}

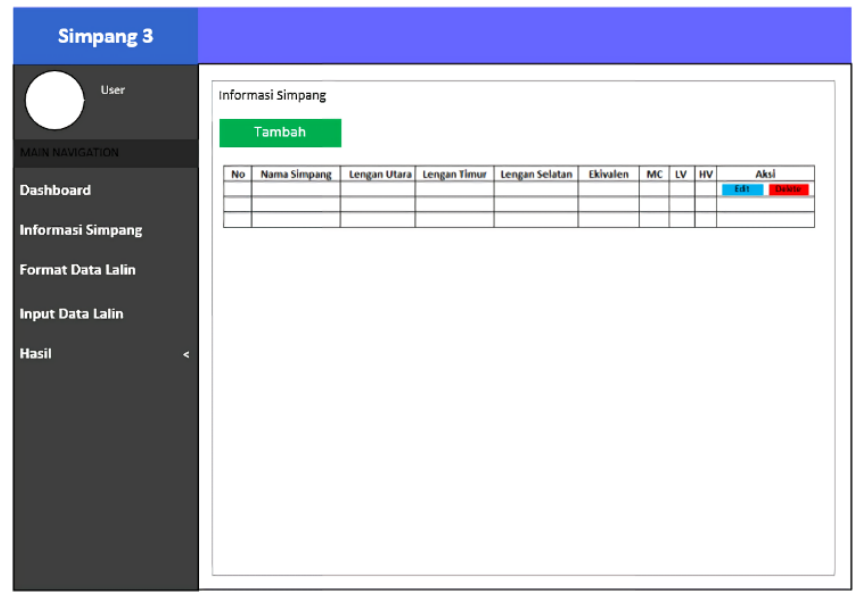

Gambar 8. Desain interface halaman informasi simpang

\section{3) Halaman Format Data Lalin:}

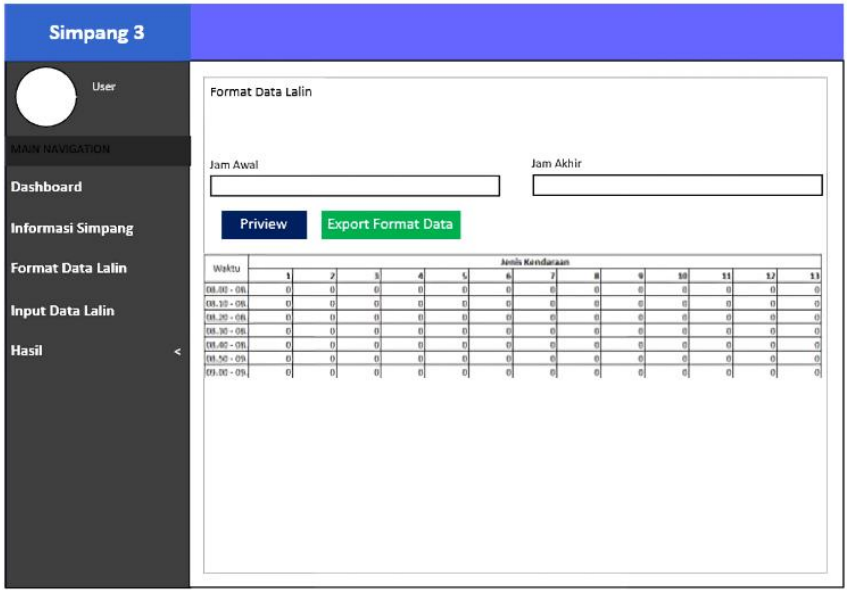

Gambar 9. Desain interface halaman format data lalin

\section{4) Halaman Input Data Lalin:}

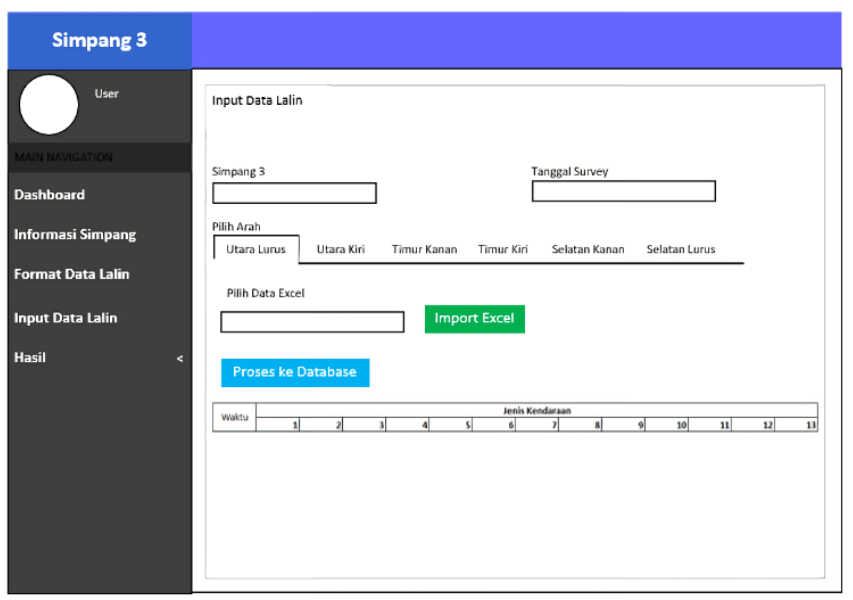

Gambar 10. Desain interface halaman input data lalin

\section{5) Halaman Hasil:}

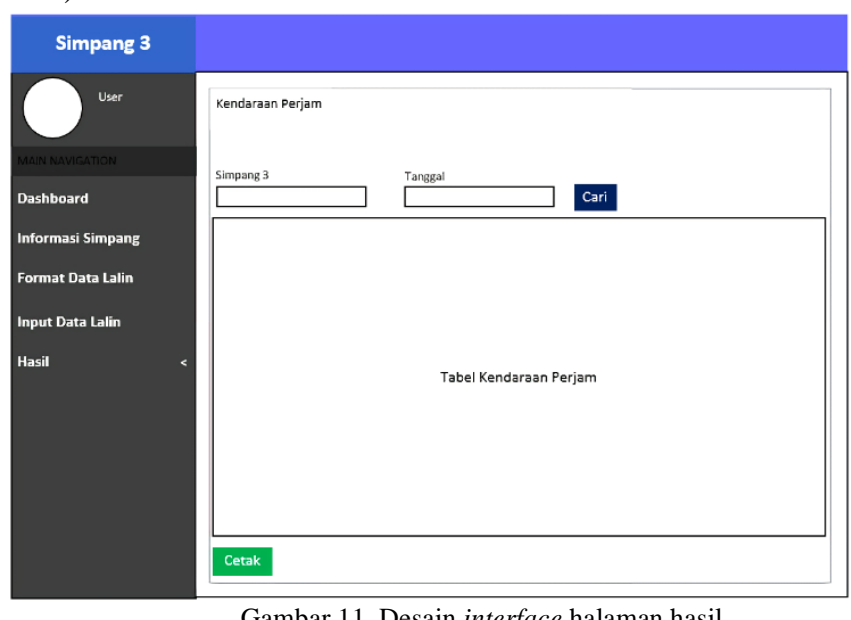

Gambar 11. Desain interface halaman hasil

\section{Proses Pengolahan Data}

Proses pengolahan data pada sistem identifikasi arus lalu lintas pada simpang tiga menggunakan database NoSQL meliputi kendaraan per-jam, satuan mobil penumpang perjam, fluktuasi lalu lintas, komposisi jumlah kendaraan, komposisi pergerakan kendaraan dan data arus lalu lintas pada jam puncak. Berikut ini adalah penjelasan dalam diagram alir mengenai proses pengolahan data pada sistem, yaitu:

1) Proses Kendaraan Per-jam: Proses pengolahan data untuk menghasilkan kendaraan per-jam dapat dilihat pada gambar 12 .

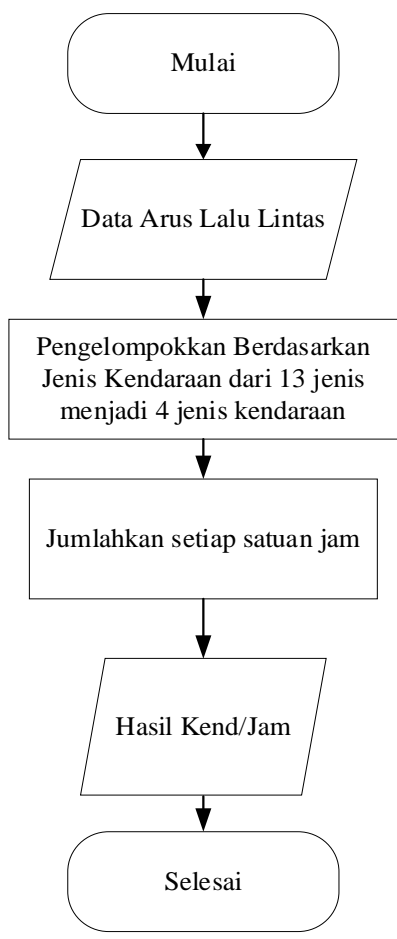

Gambar 12. Diagram alir proses pengolahan kendaraan per-jam 
2) Proses SMP Per-jam: Proses pengolahan data untuk menghasilkan SMP per-jam dapat dilihat pada gambar 13 .

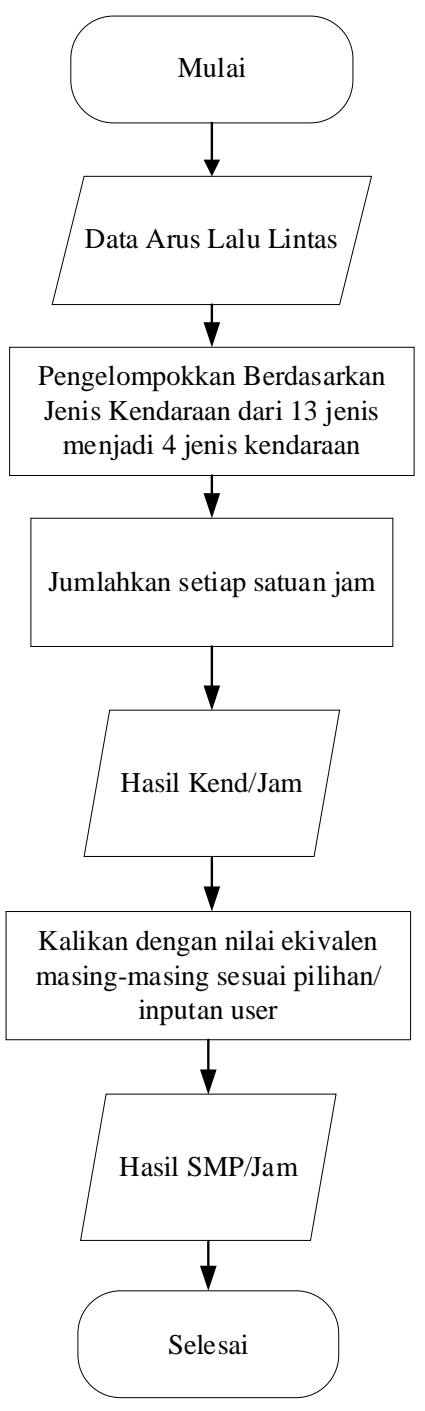

Gambar 13. Diagram alir proses pengolahan SMP per-jam

3) Proses Fluktuasi Lalu Lintas: Proses pengolahan data untuk menghasilkan fluktuasi lalu lintas dapat dilihat pada gambar 14 . 


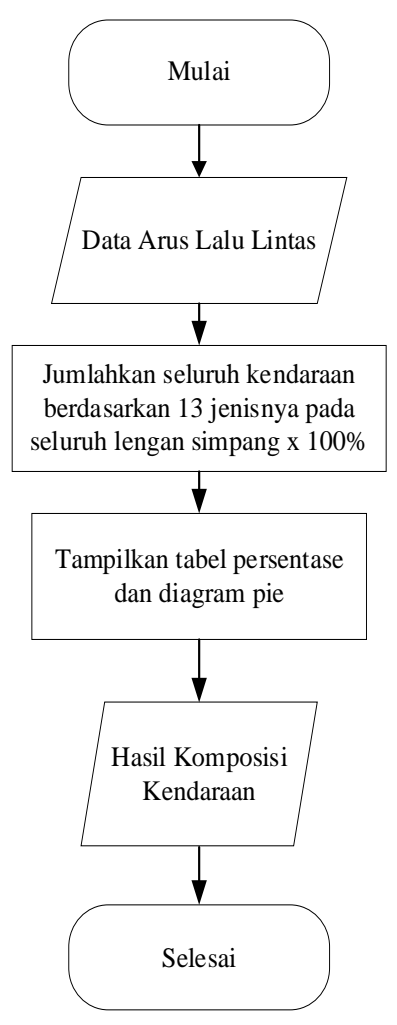

Gambar 15. Diagram alir proses pengolahan komposisi kendaraan

5) Proses Komposisi Pergerakan: Proses pengolahan data untuk menghasilkan komposisi pergerakan dapat dilihat pada gambar 16 .

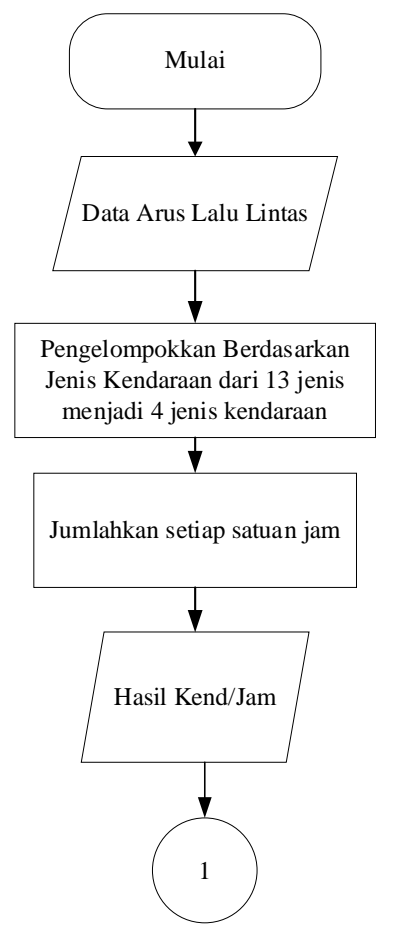

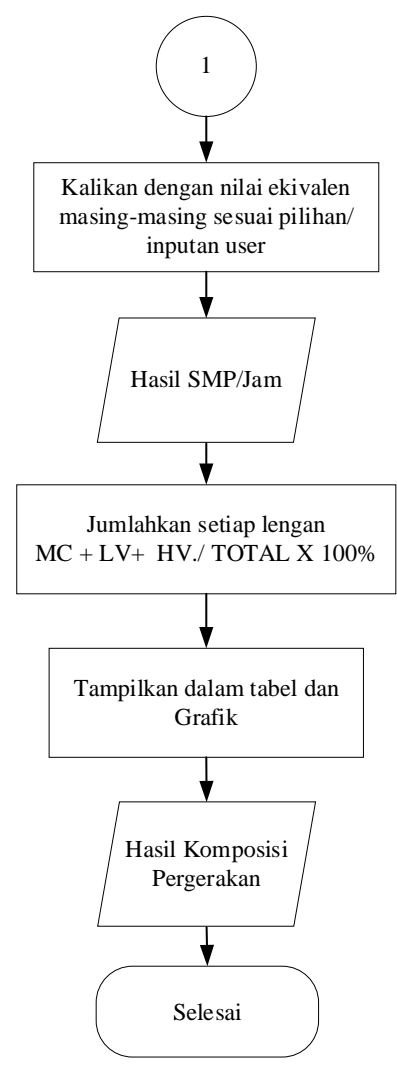

Gambar 16. Diagram alir proses pengolahan komposisi pergerakan

6) Proses Jam Puncak: Proses pengolahan data untuk menghasilkan arus lalu lintas pada jam puncak dan pendekat dapat dilihat pada gambar 17.

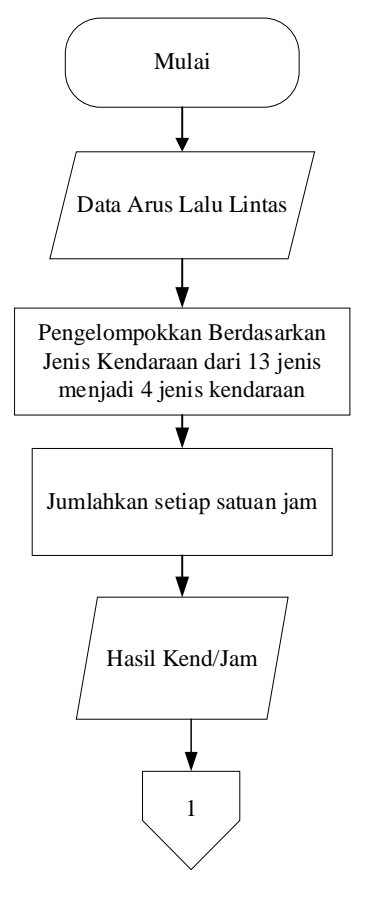




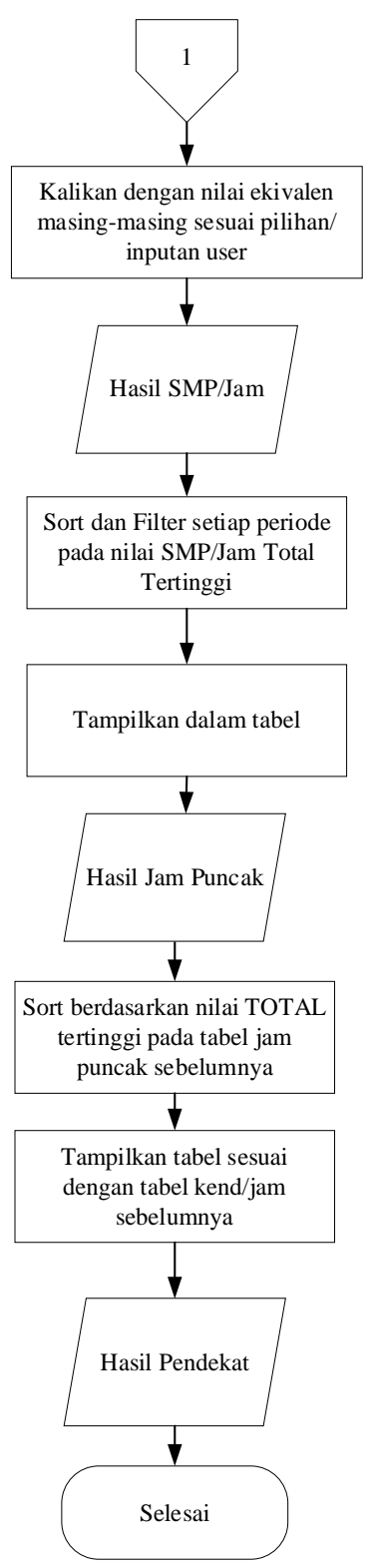

Gambar 17. Diagram alir proses pengolahan jam puncak dan pendekat

\section{E. Implementasi Interface Sistem}

Implementasi interface pada rancang bangun sistem identifikasi arus lalu lintas pada simpang tiga menggunakan database NoSQL meliputi halaman dashboard, halaman informasi simpang, halaman format data lalin, halaman input data lalin, dan halaman hasil. Berikut ini adalah penjelasan mengenai interface sistem.

1) Halaman Dashboard: Halaman dashboard merupakan tampilan awal dari sistem identifikasi arus lalu lintas pada simpang tiga menggunakan database NoSQL. Halaman ini menampilkan keterangan mengenai petunjuk penggunaan sistem. Selain itu, halaman dashboard menampilkan tabel dari 13 jenis kendaraan yang digunakan dalam sistem identifikasi arus lalu lintas pada simpang tiga menggunakan database NoSQL. Tampilan untuk halaman dashboard dapat dilihat pada gambar 18.
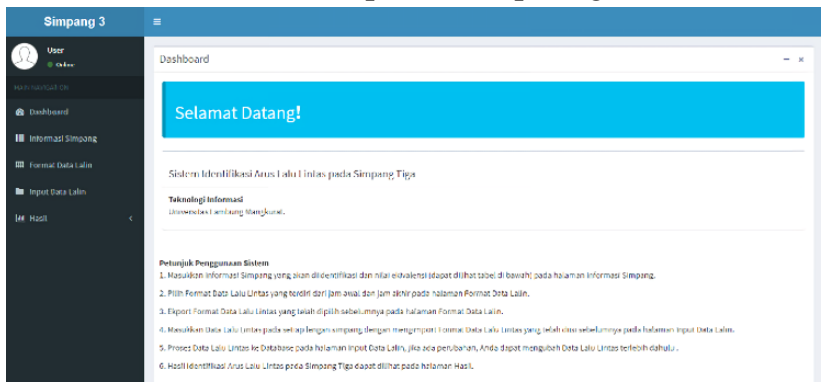

Gambar 18. Tampilan halaman dashboard

2) Halaman Informasi Simpang: Halaman tampilan informasi simpang akan menampilkan data dari suatu simpang tiga. Halaman ini menampilkan tombol tambah apabila ingin menambahkan data baru. Di halaman informasi simpang juga terdapat tombol ubah dan hapus, yang digunakan untuk mengubah ataupun menghapus data dari suatu simpang tiga. Tampilan untuk halaman informasi simpang dapat dilihat pada gambar 19 .

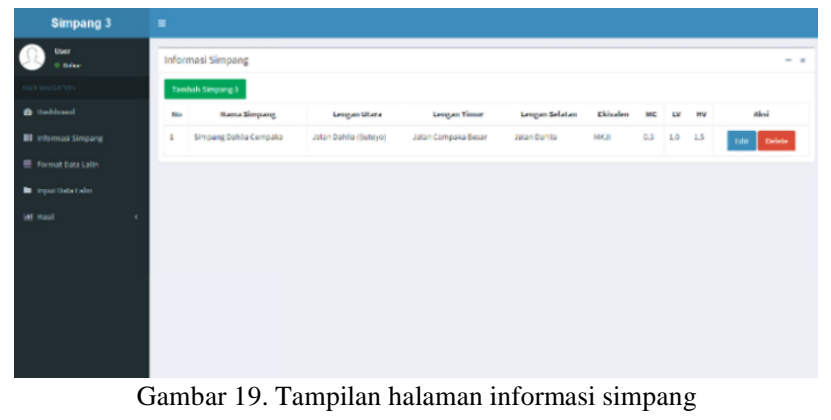

3) Halaman Format Data Lalin: Halaman format data lalin pengguna dapat memilih format data lalu lintas yang ingin diidentifikasi yaitu berdasarkan rentang waktu dilakukannya survei. Pengguna memilih jam awal survei dan jam akhir survei dilakukan, otomatis sistem akan memberi interval per-10 menit. Pengguna dapat melihat format data lalin terlebih dahulu dengan mengklik tombol preview sebelum melakukan eksport pada format data lalin dalam bentuk Excel. Tampilan untuk halaman format data lalin dapat dilihat pada gambar 20 .

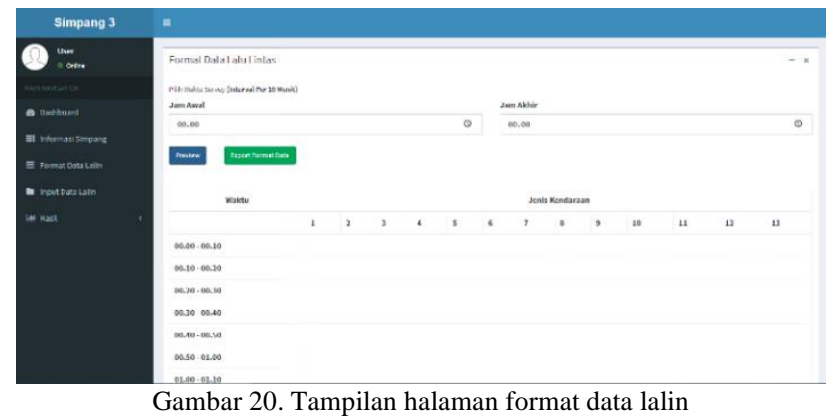


4) Halaman Input Data Lalin: Halaman input data lalin pengguna dapat memilih simpang tiga, arah simpang dan tanggal survei yang akan di-input data lalu lintasnya. Kemudian pengguna memilih file data lalu lintas dalam format Excel pada setiap arah simpang yang akan di-input data lalu lintasnya. Pengguna mengklik tombol Import Excel untuk meng-import data lalu lintas kemudian pengguna dapat melihat data lalin yang akan di-input sebelum dimasukkan ke dalam database sistem. Pengguna dapat merubah data lalu lintas terlebih dahulu apabila ada kesalahan. Setelah data lalu lintas sudah benar, maka pengguna dapat mengklik tombol proses ke database untuk memasukkan data lalu lintas ke dalam database sistem. Tampilan untuk halaman input data lalin dapat dilihat pada gambar 21 .
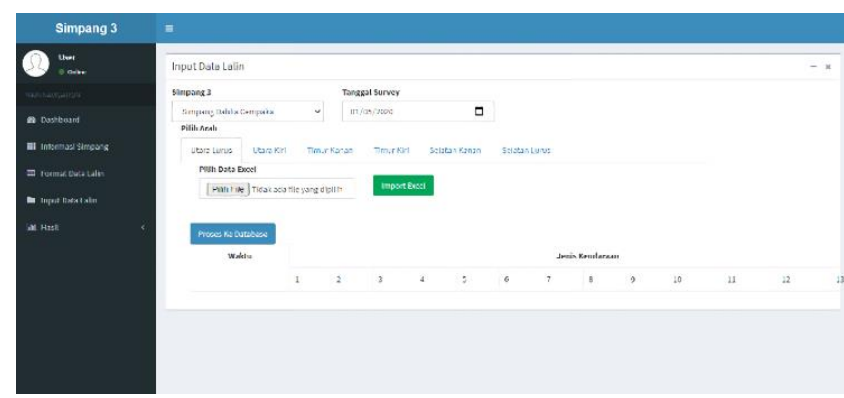

Gambar 21. Tampilan halaman input data lalin

5) Halaman Hasil: Halaman tampilan hasil menampilkan hasil kendaraan per-jam, hasil SMP per-jam, hasil fluktuasi lalu lintas, hasil komposisi kendaraan, hasil komposisi pergerakan, hasil arus lalu lintas pada jam puncak Apabila pengguna ingin mencetak hasil kendaraan per-jam suatu simpang tiga pada tanggal survei yang telah dipilih, sistem menyediakannya pada halaman ini dengan fitur cetak pada tombol cetak berwarna hijau yang terdapat di bawah kiri halaman. Tampilan untuk halaman hasil kendaraan per-jam dapat dilihat pada gambar 22.

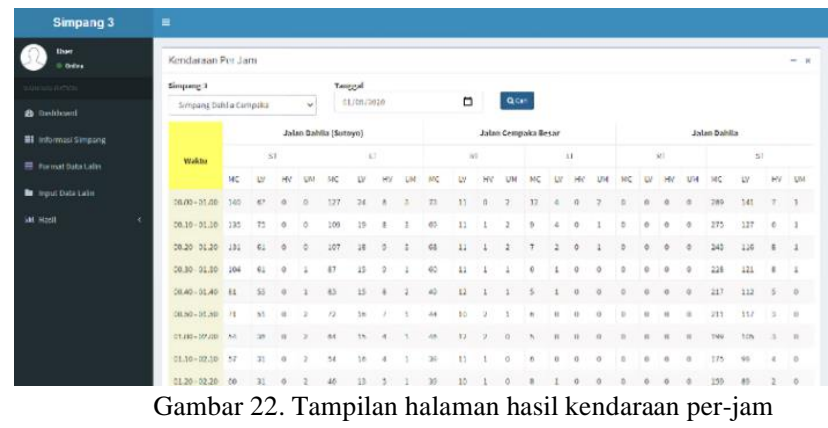

\section{F. Perbandingan dengan Database MySQL}

Desain database MySQL untuk sistem identifikasi arus lalu lintas pada simpang tiga. Berbeda dengan NoSQL yang membutuhkan collection, pada database MySQL menggunakan 3 tabel yaitu tabel ekivalen, tabel simpang3 dan tabel data_lalin. Tabel ekivalen mempunyai 5 field yaitu id_ekivalen sebagai primary key, jenis_ekivalen, nilai mc, lv dan hv. Tabel simpang3 mempunyai 6 field yaitu id_simpang3 sebagai primary key, id_ekivalen, nama_simpang3, nama_jalan_utara, nama_jalan_timur dan nama_jalan_selatan. Tabel data_lalin mempunyai 83 field yaitu id_data_lalin sebagai primary key, id_simpang3, jam_awal, jam_akhir dan data dari 13 jenis kendaraan yang berbeda pada setiap arah simpang yang disimpan setiap interval 10 menit. Desain database menggunakan MySQL dapat dilihat pada gambar 23.
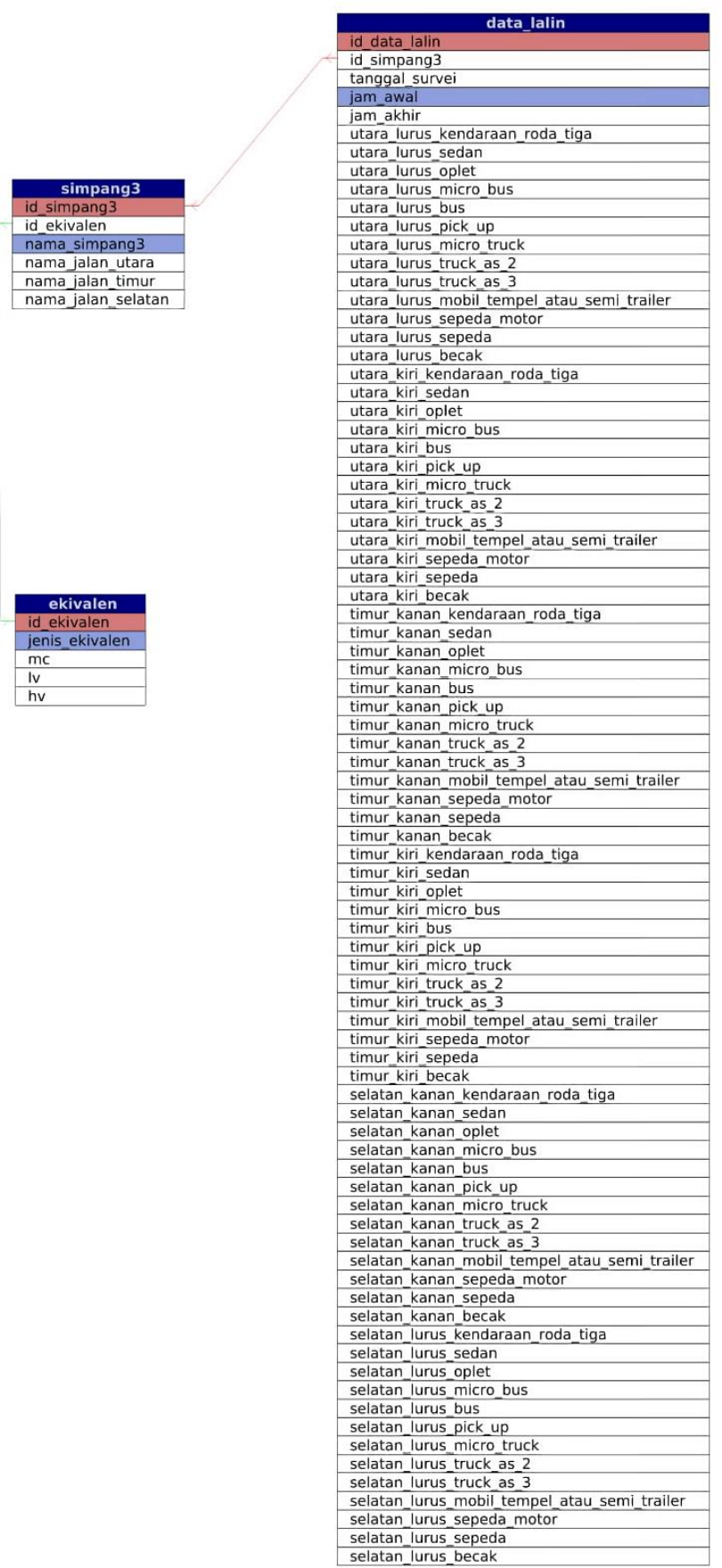

Gambar 23. Desain database $M y S Q L$ 


\section{G. Database MySQL dengan Data Real}

Data real yang digunakan dalam sistem identifikasi arus lalu lintas pada simpang tiga merupakan data real dari survei lalu lintas pada simpang tiga Dahlia Cempaka Banjarmasin pada tanggal 25 Juli 2019. Database MySQL sistem identifikasi arus lalu lintas pada simpang tiga dengan menggunakan data real dapat dilihat pada gambar 24.

$\begin{array}{rllll}\text { id_ekivalen } & \text { jenis_ekivalen } & \mathbf{m c} & \mathbf{I v} & \mathbf{h v} \\ 1 & \mathrm{MKJI} & 0.3 & 1.0 & 1,5\end{array}$

\section{pilihan: Ubah \\ Gambar 24. Data real tabel ekivalen pada $M y S Q L$}

Gambar 24 menunjukkan data real pada tabel ekivalensi pada $M y S Q L$ Data real pada tabel ekivalen merupakan data yang menyimpan nilai ekivalensi dari simpang tiga yang terdiri dari id_ekivalen, jenis_ekivalen, nilai motorcycle (mc), nilai light vehicle (lv) dan nilai heavy vehicle (hv).

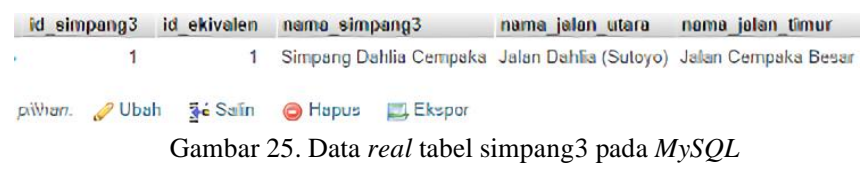

Gambar 25 menunjukkan data real pada tabel simpang3 pada $M y S Q L$. Data real pada tabel simpang3 merupakan data yang menyimpan informasi dari simpang tiga yang terdiri dari id_simpang3, id_ekivalen, nama_simpang3, nama_jalan_utara, nama_jalan_timur dan nama_jalan_selatan.

\begin{tabular}{|rrrrrr|} 
id_data_lalin & id_simpang & tanggal_survei & jam_awal & jam_akhir & utaralurus_kendaraan_roda_tiga \\
\hline 1 & 1 & $2020-05-01$ & 00.00 & 00.10 & 0 \\
\hline 2 & 1 & $2020-05-01$ & 00.10 & 00.20 & 0 \\
\hline 3 & 1 & $2020-05-01$ & 00.20 & 00.30 & 0 \\
\hline 4 & 1 & $2020-05-01$ & 00.30 & 00.40 & 0 \\
\hline 5 & 1 & $2020-05-01$ & 00.40 & 00.50 & 0 \\
\hline 6 & 1 & $2020-05-01$ & 00.50 & 01.00 & 0 \\
\hline 7 & 1 & $2020-05-01$ & 01.00 & 01.10 & 0 \\
\hline 8 & 1 & $2020-05-01$ & 01.10 & 01.20 & 0 \\
\hline 9 & 1 & $2020-05-01$ & 01.20 & 01.30 & 0 \\
\hline 10 & 1 & $2020-05-01$ & 01.30 & 01.40 & 0 \\
\hline 11 & 1 & $2020-05-01$ & 01.40 & 01.50 & \\
\end{tabular}

Gambar 26 menunjukkan data real pada tabel data_lalin pada $M y S Q L$ Data real pada tabel data_lalin merupakan data yang menyimpan data lalu lintas dari simpang tiga dalam setiap interval 10 menit yang terdiri dari id_data_lalin, id_simpang3, jam_awal, jam_akhir dan data dari 13 jenis kendaraan yang berbeda pada setiap arah simpang. Proses peng-import-an data ke dalam database MySQL rata-rata membutuhkan waktu 3,86 detik.

\section{H. Database NoSQL dengan Data Real}

Database NoSQL untuk sistem identifikasi arus lalu lintas pada simpang tiga dengan menggunakan data real yaitu data survei lalu lintas pada simpang tiga Dahlia Cempaka
Banjarmasin pada tanggal 25 Juli 2019. Database NoSQL, data 13 jenis kendaraan disimpan dengan array pada setiap arah simpang per-10 menit. Data ini nantinya dapat dijadikan dataset yang bisa dimanfaatkan untuk pengembangan machine learning. Proses peng-import-an data ke dalam database NoSQL rata-rata hanya membutuhkan waktu 1,66 detik. Database NoSQL sistem identifikasi arus lalu lintas pada simpang tiga dengan

\section{trafficapps.DataLaluLintas}

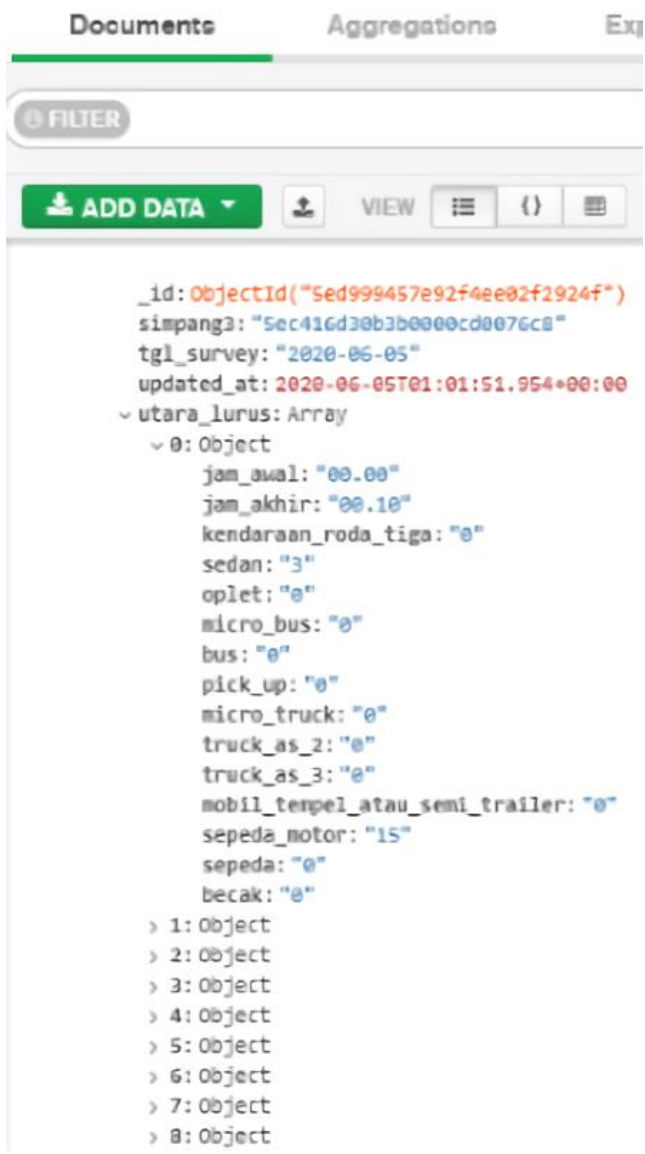

menggunakan data real dapat dilihat pada gambar 27.

Gambar 27. Data real pada $N o S Q L$

\section{Perbandingan Waktu Pemroresan}

Perbandingan waktu peng-import-an dengan menggunakan data real yang telah dilakukan sebelumnya, NoSQL lebih cepat dibandingan dengan MySQL. MySQL rata-rata membutuhkan waktu 3,86 detik sedangkan NoSQL rata-rata hanya membutuhkan waktu 1,66 detik. Selanjutnya untuk mengetahui waktu yang dibutuhkan sistem untuk pemrosesan identifikasi arus lalu lintas pada simpang tiga dan menghasilkan 6 hasil identifikasi yaitu data kendaraan per-jam, satuan mobil penumpang per-jam, fluktuasi lalu lintas, komposisi jumlah kendaraan, komposisi pergerakan kendaraan dan data arus lalu lintas pada jam puncak, maka dilakukan uji coba. Kemudian waktu pemrosesan 
dibandingkan dengan menggunakan Microsoft Excel, MySQL dan NoSQL. Adapun hasil uji coba waktu yang dibutuhkan untuk mengidentifikasi arus lalu lintas pada simpang tiga menggunakan Microsoft Excel dapat dilihat pada tabel II.

TABEL II

Hasil Uji COBA MENGGUNAKAN MicRosoft ExCEL

\begin{tabular}{|c|l|c|}
\hline No & Percobaan & Waktu (detik) \\
\hline 1 & Percobaan 1 & $2.068,9$ \\
\hline 2 & Percobaan 2 & $1.932,3$ \\
\hline 3 & Percobaan 3 & $1.779,1$ \\
\hline 4 & Percobaan 4 & $1.841,3$ \\
\hline 5 & Percobaan 5 & $1.716,8$ \\
\hline \multicolumn{2}{|c|}{ Rata-rata } & $1.867,7$ \\
\hline
\end{tabular}

Setelah melakukan uji coba waktu yang dibutuhkan untuk mengidentifikasi arus lalu lintas pada simpang tiga menggunakan Microsoft Excel, selanjutnya akan dilakukan uji coba waktu yang dibutuhkan untuk mengidentifikasi arus lalu lintas dengan menggunakan MySQL. Hasil uji coba waktu yang dibutuhkan untuk mengidentifikasi arus lalu lintas pada simpang tiga untuk menghasilkan 6 hasil identifikasi yaitu data kendaraan per-jam, satuan mobil penumpang per-jam, fluktuasi lalu lintas, komposisi jumlah kendaraan, komposisi pergerakan kendaraan dan data arus lalu lintas pada jam puncak menggunakan MySQL dapat dilihat pada tabel III.

TABEL III

HASIl UJi COBA MENGGUNAKAN MYSQL

\begin{tabular}{|c|l|c|}
\hline No & Percobaan & Waktu (detik) \\
\hline 1 & Percobaan 1 & 79,5 \\
\hline 2 & Percobaan 2 & 76,1 \\
\hline 3 & Percobaan 3 & 84,4 \\
\hline 4 & Percobaan 4 & 73,9 \\
\hline 5 & Percobaan 5 & 78,3 \\
\hline \multicolumn{2}{|c|}{ Rata-rata } & 78,4 \\
\hline \multicolumn{2}{|c|}{}
\end{tabular}

Setelah melakukan uji coba waktu yang dibutuhkan untuk mengidentifikasi arus lalu lintas pada simpang tiga menggunakan $M y S Q L$, selanjutnya akan dilakukan uji coba waktu yang dibutuhkan untuk mengidentifikasi arus lalu lintas dengan menggunakan NoSQL. Hasil uji coba waktu yang dibutuhkan untuk mengidentifikasi arus lalu lintas pada simpang tiga untuk menghasilkan 6 hasil identifikasi yaitu data kendaraan per-jam, satuan mobil penumpang perjam, fluktuasi lalu lintas, komposisi jumlah kendaraan, komposisi pergerakan kendaraan dan data arus lalu lintas pada jam puncak menggunakan NoSQL dapat dilihat pada tabel IV.
TABEL IV

HASIl UJi COBA MENGGUNAKAN NOSQL

\begin{tabular}{|c|l|c|}
\hline No & Percobaan & Waktu (detik) \\
\hline 1 & Percobaan 1 & 73,4 \\
\hline 2 & Percobaan 2 & 70,0 \\
\hline 3 & Percobaan 3 & 78,1 \\
\hline 4 & Percobaan 4 & 69,8 \\
\hline 5 & Percobaan 5 & 72,4 \\
\hline \multicolumn{2}{|c|}{ Rata-rata } & 72,7 \\
\hline
\end{tabular}

\section{J. Hasil Pengujian Blackbox}

Untuk mengetahui apakah sistem dibuat berjalan sesuai dengan yang dikerjakan, maka dilakukan uji coba sistem secara fungsional. Dalam pengujian sistem yang sudah dibuat dilakukan dengan cara pengujian blackbox. Adapun hasil pengujian blackbox sistem dapat dilihat pada tabel V.

TABEL V

Hasil Pengujian Dengan Metode Blackbox

\begin{tabular}{|l|c|l|}
\hline \multicolumn{1}{|c|}{ Pengujian } & Hasil & \multicolumn{1}{|c|}{$\begin{array}{c}\text { Syarat dalam } \\
\text { pengujian }\end{array}$} \\
\hline $\begin{array}{l}\text { Pengguna melihat } \\
\text { data simpang tiga }\end{array}$ & Berhasil & $\begin{array}{l}\text { Pengguna dapat } \\
\text { melihat data } \\
\text { simpang tiga }\end{array}$ \\
\hline $\begin{array}{l}\text { Pengguna menambah } \\
\text { data simpang tiga }\end{array}$ & Berhasil & $\begin{array}{l}\text { Pengguna dapat } \\
\text { menambah data } \\
\text { simpang tiga }\end{array}$ \\
\hline $\begin{array}{l}\text { Pengguna } \\
\text { memasukkan nilai } \\
\text { ekivalensi }\end{array}$ & Berhasil & $\begin{array}{l}\text { Pengguna dapat } \\
\text { memasukkan nilai } \\
\text { ekivalensi }\end{array}$ \\
\hline $\begin{array}{l}\text { Pengguna mengunduh } \\
\text { format data lalin }\end{array}$ & Berhasil & $\begin{array}{l}\text { Pengguna dapat } \\
\text { mengunduh format } \\
\text { data lalin }\end{array}$ \\
\hline $\begin{array}{l}\text { Pengguna memilih } \\
\text { format data lalin }\end{array}$ & Berhasil & $\begin{array}{l}\text { Pengguna dapat } \\
\text { memilih format data } \\
\text { lalin }\end{array}$ \\
\hline $\begin{array}{l}\text { Pengguna melihat } \\
\text { data survei }\end{array}$ & Berhasil & $\begin{array}{l}\text { Pengguna dapat } \\
\text { melihat data survei }\end{array}$ \\
\hline $\begin{array}{l}\text { Pengguna menambah } \\
\text { data survei }\end{array}$ & Berhasil & $\begin{array}{l}\text { Pengguna dapat } \\
\text { menambah data } \\
\text { survei }\end{array}$ \\
\hline $\begin{array}{l}\text { Pengguna melihat } \\
\text { hasil identifikasi }\end{array}$ & Berhasil & $\begin{array}{l}\text { Pengguna dapat } \\
\text { melihat hasil } \\
\text { identifikasi }\end{array}$ \\
\hline
\end{tabular}

\section{KESIMPULAN}

Berdasarkan penelitian yang telah dilakukan, dapat ditarik kesimpulan bahwa dengan dibangunnya sistem ini telah dapat memudahkan proses identifikasi arus lalu lintas pada simpang tiga yang umumnya dilakukan dengan menggunakan Microsoft Excel. Sistem ini dapat menghemat waktu pemrosesan menjadi sangat signifikan. Pemrosesan manual dengan Excel yang rata-rata membutuhkan waktu 
sekitar 31 menit dapat dipangkas sehingga hanya membutuhkan waktu sekitar 1 menit. Sistem ini juga meminimalkan terjadinya human error terutama dalam proses sort dan filter. Penggunaan database NoSQL dengan MongoDB juga dapat membuat proses impor data menjadi lebih efisien dengan rata-rata waktu 1,66 detik dibandingkan dengan $M y S Q L$ yang membutuhkan rata-rata waktu 3,86 detik. Diharapkan kedepannya sistem dapat dikembangkan untuk mengidentifikasi arus lalu lintas pada jenis simpang lainnya seperti simpang empat dan simpang lima.

\section{DAFTAR PUSTAKA}

[1] C. Oglesby \& R. Hicks, Teknik Jalan Raya, Jakarta: Erlangga, 1999.

[2] M. Rahmah, "Analisis Simpang Tiga Jalan Pramuka - Jalan Veteran Banjarmasin," skripsi, Universitas Lambung Mangkurat, Banjarmasin, 2019.

[3] S. Wulandari, "Analisis Simpang Tiga Jalan Beruntung Jaya - Jalan Raya Yudistira Banjarmasin," skripsi, Universitas Lambung Mangkurat, Banjarmasin, 2019.

[4] T. Fujishakti, "Evaluasi Simpang Tiga Tak Bersinyal Jalan Sungai Andai - Jalan Padat Karya Banjarmasin," skripsi, Universitas Lambung Mangkurat, Banjarmasin, 2019.
[5] H. Budi, A. Wicaksono \& M. Anwar, "Evaluasi Kinerja Simpang Tidak Bersinyal Jalan Raya Mengkreng Kabupaten Jombang," Jurnal Rekayasa Sipil., vol. 8, no. 3, pp. 174-180, 2014.

[6] Z. Parker, S. Poe, \& S. V Vrbsky, Comparing NoSQL MongoDB to an SQL DB, Proceedings of the 51st ACM Southeast Conference, April 2013, pp. 1-6, https://doi.org/10.1145/2498328.2500047.

[7] W. Suliyanti, "Studi Literatur Basis Data SQL dan NoSQL," Jurnal Kilat., vol. 8, no. 1, pp. 48-51, 2019.

[8] A. Junaidi, "Studi Perbandingan Performansi Antara MongoDB dan MySQL Dalam Lingkungan Big Data," Prosiding Annual Research Seminar., vol. 2, no.1, 2016, pp.460-465.

[9] F. Bhaswara, R. Sarno \& D. Sunaryono, "Perbandingan Kemampuan Database NoSQL dan SQL dalam Kasus ERP Retail," Jurnal Teknik ITS., vol. 6, no. 2, pp. 510-514, 2017.

[10] S. Chickerur, A. Goudar \& A. Kinnerkar, "Comparison of Relational Database with Document-Oriented Database (MongoDB) for Big Data Applications," 2015 8th International Conference on Advanced Software Engineering \& Its Applications (ASEA)., 2015, pp. 41-47.

[11] I. Bastian, R. Winardi \& D. Fatmawati, Metoda Wawancara dalam Metoda Pengumpulan dan Teknik Analisis Data, Yogyakarta: Andi, 2018.

[12] M. Nazir, Metode Penelitian, Bogor: Ghalia Indonesia, 2013.

[13] Indrajani, Perancangan Basis Data dalam All in 1, Jakarta: Elex Media Komputindo, 2011.

[14] A. Rosa \& M. Shalahuddin, Rekayasa Perangkat Lunak Struktur dan Berorientasi Objek, Bandung: Informatika, 2014. 